\title{
FREQUENCY OF THE CLINICAL TYPES OF LEPROSY ACCORDING TO THE NATURAL REGIONS OF BRAZIL
}

by

JOAO BATISTI RISI

(Reprinted from International Journal of Leprosy, 15, 246)

Prior to the present time no study has been made of the endemic phase of leprosy in the various physiographical districts of Brazil. Such studies are important since it is known that there is a relationship between the frequency of leprosy in an area and its mesological conditions. The distribution of leprosy varies greatly in different parts of the globe. Many believe that even though biological and sociological factors are important in determining the preva-lence of the disease, mesological factors are of still greater importance. Similar conclusions must be reached whether dealing with infectious diseases or with those of a somatologic order. The variations in climatic elements: temperature, atmospheric pressure, winds, rains, and relative humidity determine in the majority of pathological conditions, changes either for better or for worse.

The nosographic map of the globe shows that certain diseases are more prevalent in some areas than in others. Climatic conditions may operate intrinsically, by affecting the functional equilibrium of the individual, or extrinsically by creating environmental factors necessary for the development of the infective agent. Mesological conditions also influence social customs, which vary as to whether the region is tropical or not. These affect the hygienic and dietary habits of the population, and so the entire conditions, of life.

With these facts in mind, it was decided to study the material in the central archives of the National Leprosy Service of Brazil, consisting of records of 39,475 patients. Both the clinical form of leprosy and the physiographical characteristics including climatic conditions in each area were analyzed.

The same regional division as given by the Federal Council of Geography was adopted. This serves better than a simple administrative division by states, as it allows a grouping of areas according to the mesological characteristics which differentiate the various regions. However, it is convenient within the divisions to consider each separate federal unit, even though it means some delimitation 
of the regions, for the natural frontiers do not always coincide with the administrative divisions. Nevertheless the regional grouping defines the zones that are more or less homogeneous and almost uniformly subject to the same meteorological conditions.

Clinical types were classified according to the Cairo classification, since it is universally used. An attempt was made to establish the parallelism between the frequency of the lepromatous and the tuberculoid types, since these are distinct both clinically and epidemiologically, and the mesological characteristics of the region.

The country was divided into 5 physiographical regions: (a) Northern; (b) Northeastern; (c) Eastern; (d) Southern, and (e) West-Central.

I. Northem region: The states that comprise this region are: Amazonas, Pará and the territories of Guaporé, Acre, Rio Branco, and Amapá. This is an equatorial region, the equator dividing it in two parts of which the part north of the equator is the smaller. Within this region is the vast Amazon plain, which because of its different aspects again is divided into three natural regions: (a) bordering the Guianas on the North: (b) the Central Amazon Plain, and (c) bordering the Brazilian Highland on the south. These regions all border on the Amazon River. The northern region has the highest prevalence of leprosy in all Brazil, varying from 1.0 to 3.8 per Iooo population, according to data published by the National Leprosy Service. The rates for the individual administrative units in this region are as follows:

$\begin{array}{lccc}\text { Amazonas } & 3.8 & \text { pcr } & \text { Iooo } \\ \text { Acre } & 3.5 & , & , \\ \text { Pará } & 3.3 & , & , \\ \text { Guaporé } & \text { I.2 } & , & , \\ \text { Amapá } & \text { I.I } & , & , \\ \text { Rio Branco } & \text { I.0 } & , & , \\ & & \end{array}$

Of a total of 2763 cases, 2697 or 97 per cent were in the Amazon plain. In the region bordering the Guianas there were 42 cases and in the region on the northern border of the Brazilian Highland only 24.

The region bordering the Guianas includes also a small section of the littoral of the state of Pará. The soil is of a gneissic granite rocky type, the topography being very irregular. The climate in this region is torrid and humid. 
The second region, the Amazon Plain, includes all the vast Amazon basin and extends from the Para littoral, in that portion which covers the mouth of the Amazon, and penetrates into the interior, spreading over the centre of the northern region. In this region the climate is also hot and humid with little variation in temperature. Rainfall is abundant and the entire area is richly Govered with vegetation. This region is especially important as regards leprosy because of the large numbers of cases found.

The third region of the north-the northern border of the Brazilian Highland--has a climate differing little from the other two.

TABLE: I

Distribution of the clinical types of leprosy in the natural regions of North Brazil:*

\begin{tabular}{|c|c|c|c|c|c|c|c|c|c|}
\hline \multirow{4}{*}{$\begin{array}{l}\text { Natural } \\
\text { regions }\end{array}$} & \multicolumn{8}{|c|}{ (:linical Types } & \multirow{4}{*}{ Total } \\
\hline & & & & & Neu & & & & \\
\hline & \multicolumn{2}{|c|}{$\begin{array}{l}\text { I.epro- } \\
\text { matous }\end{array}$} & \multicolumn{2}{|c|}{ Anatestlestic } & \multicolumn{2}{|c|}{$\begin{array}{l}\text { Macular } \\
\text { simple: }\end{array}$} & \multicolumn{2}{|c|}{$\begin{array}{l}\text { Maculair } \\
\text { tuberculiod }\end{array}$} & \\
\hline & No. & $\begin{array}{l}\text { Per } \\
\text { cent }\end{array}$ & No. & $\begin{array}{l}\text { Per } \\
\text { cent }\end{array}$ & No. & $\begin{array}{l}\text { Per } \\
\text { cent }\end{array}$ & No. & $\begin{array}{l}\text { Per } \\
\text { cent }\end{array}$ & \\
\hline $\begin{array}{l}\text { Guiana } \\
\text { Frontier }\end{array}$ & 14 & 34.1 & 12 & 29.3 & 9 & 22.0 & 6 & 14.6 & 41 \\
\hline $\begin{array}{l}\text { Amazon } \\
\text { Plain }\end{array}$ & 1.389 & 52.0 & 722 & 27.1 & 476 & 17.8 & 82 & 3.1 & 2,669 \\
\hline $\begin{array}{l}\text { Northern } \\
\text { Frontier } \\
\text { of } \\
\text { Brazilian } \\
\text { Highland }\end{array}$ & 9 & 39.1 & 9 & 39.1 & 5 & 21.8 & $\cdots$ & $\cdots$ & 23 \\
\hline TOTAI & 1,412 & $\ldots$ & 743 & $\cdots$ & 490 & $\ldots$ & 88 & $\ldots$ & 2,733 \\
\hline
\end{tabular}

*3o cases are exclucled in which the clinical type was unknown.

Table I shows the distribution of cases in the northern region according to clinical type. Not only does the Amazon plain have the most cases, but also the highest proportion of lepromatous cases. In this region the density of population is greatest, for the people wish to live near lines of communication and resources. Climatic conditions are unfavourable. These factors combined with others such as sub-nutrition and endemic diseases are conducive to the spread of leprosy. 
II. The Norlb-east region: Included in this region are the states of Maranhão, Piauí, Rio Grande do Norte, Paraiba, Pernambuco, and Alagôas. It occupies an extensive area between the Amazon Plain and the mountainous region to the east of Brazil. It is divided into three physiographic parts: (a) littoral, (b) forest, and (c) lowland. This region has the lowest prevalence rate for leprosy, the highest rate being less than I per Iooo inhabitants. The rates for the separate states are as follows:

\begin{tabular}{|c|c|c|}
\hline Maranhão & 0.9 & per \\
\hline Piauí & 0.5 & ", \\
\hline Ceará & 0.5 & ,", \\
\hline Paraiba & 0.5 & , , \\
\hline Rio Grande do Norte & 0.3 & ," \\
\hline Pernambuco & O.I & , , \\
\hline Alagôas & 0.0005 & , \\
\hline
\end{tabular}

In this region there were 2962 cases distributed according to natural regions as follows:

$\begin{array}{lll}\text { (a) Littoral } & \text { North } & 908 \text { Cases } \\ & \text { East and coastal } & 744 \quad, \\ \text { (b) Semi arid } & \text { Forest } & 925 \\ & \text { Lowland swamps, fields } & 385\end{array}$

The mesological characteristics of this region are very similar to those of the northern region. The prevalence of leprosy decreases in proportion as these characteristics become differentiated from those of that region. Thus the highest rate is in the state of Maranhão where natural conditions are most like those of the northern region.

The four areas in this region have marked differences. In the northern littoral, rain is scarce and there are heavy deposits of sand, forming beaches and dunes. On the east littoral, the rainfall is more abundant. In the interior region, the climate is noted for its extensive periods of dry weather, often lasting for as long as eight months. Periodically droughts of two or three years duration occur, forcing the people to emigrate. Rainfall is poorly distributed. In this semi-arid area there is a type of vegetation called " caatinga" (wiregrass). The topography shows little variation, being mainly isolated hills and table land. In the lowlands, there is more diversity in the scenery. The fluvial courses are permanent. Rainfall again is poorly distributed, but because of the 
greater permeability of the soil and less declivity of the land, is better retained.

The prevalence of the different clinical types as seen in Table 2 indicates approximately the same distribution in the different regions. As in the northern region, the lepromatous type is the type found most frequently.

III. The East region: Included in this region are the states of Sergipe, Bahia, Minas Geraes, Esperito Santo, Rio de Janeiro, and the Federal District. This region is divided into four zones, extending from north to south in the following order: (I) littoral, (2) east coast, (3) highland, and (4) the San lirancisco depression.

\section{TABLE 2: Distribution of the clinical forms of leprosy} in the natural regions of North-east Brazil*

\begin{tabular}{|c|c|c|c|c|c|c|c|c|c|}
\hline \multirow{4}{*}{$\begin{array}{l}\text { Natural } \\
\text { regions }\end{array}$} & \multicolumn{8}{|c|}{ Clinical Types } & \multirow{4}{*}{ Total } \\
\hline & \multirow{2}{*}{\multicolumn{2}{|c|}{$\begin{array}{l}\text { Lepro- } \\
\text { matous }\end{array}$}} & \multicolumn{6}{|c|}{ Neural } & \\
\hline & & & \multicolumn{2}{|c|}{ Anaesthetic } & \multicolumn{2}{|c|}{$\begin{array}{l}\text { Macular } \\
\text { simple }\end{array}$} & \multicolumn{2}{|c|}{$\begin{array}{c}\text { Macular } \\
\text { Tuberculoid }\end{array}$} & \\
\hline & No. & $\begin{array}{l}\text { Per } \\
\text { cent }\end{array}$ & No. & $\begin{array}{l}\text { Per } \\
\text { cent }\end{array}$ & No. & $\begin{array}{l}\text { Per } \\
\text { cent }\end{array}$ & No. & $\begin{array}{l}\text { Per } \\
\text { cent }\end{array}$ & \\
\hline $\begin{array}{l}\text { Littoral } \\
\text { and }\end{array}$ & 390 & 54.1 & 129 & 17.9 & 189 & 26.4 & 12 & 1.6 & 720 \\
\hline $\begin{array}{l}\text { Coastal } \\
\text { Semi- }\end{array}$ & 36 & 59.1 & 95 & 10.5 & 232 & 25.4 & 44 & 4.0 & 9() 7 \\
\hline Lowland & 171 & 46.2 & 108 & 29.2 & 88 & 23.8 & 3 & 0.8 & 370 \\
\hline Litt. N. & 505 & 58.1 & 84 & 9.6 & 244 & 28.1 & 137 & 4.3 & 870 \\
\hline TOTAL & 1,602 & $\ldots$ & 416 & $\ldots$ & 753 & $\ldots$ & 96 & $\ldots$ & 2,867 \\
\hline
\end{tabular}

*95 records are excluded because of insufficient clinical data.

In the first zone, there is a plain, consisting of tertiary and quaternary sedimentary deposits of variable width, known in certain places as "the Fluminence Lowland," in others as " the Fields of the Goitacazes." The climate is hot and humid, with heavy rainfall, especially in the summer. Winding rivers meander throughout the zone, all seeking the coast for outlet. These are favorable to agriculture. In the second zone, the climate is still hot and humid with abundant rainfall. Dense forests cover the territory, which in one place is known as "Zone of the Forests." Until very recent times the principal occupation was the growing of coffee, and today this is still one of the major industries. In 
the third zone, the topography is hilly, with high mountain peaks, the highest in Brazil. The climate is temperate, more or less humid, rainy in summer in contrast to a dry winter. In the San Francisco zone, the climate is dry. Rivers and falls are more scarce.

The prevalence of leprosy varies little except in Bahia where the rate is low. The rate per Iooo persons for the individual areas is as follows:

\begin{tabular}{|c|c|c|c|c|}
\hline Minas Geraes & I. 4 & per & 1000 & persor \\
\hline Federal District & I. 4 & ", & ,' & , \\
\hline Esperito Santo & 1.0 & , & ', & "' \\
\hline Sergipe & 0.7 & , , & $"$ & , \\
\hline Rio de Janeiro & 0.6 & , , & ", & ", \\
\hline Bahia & 0.02 & , , & ", & ," \\
\hline
\end{tabular}

There have been 16,95 I cases of leprosy in this region distributed in the natural regions as follows:

$\begin{array}{lr}\text { Littoral } & 2397 \text { cases } \\ \text { Coastal } & 5054, \\ \text { Highland } & 9177, \\ \text { Depression, San Francisco } 383 & ,\end{array}$

The ifequency of the various clinical types in the different zones is given in Table 3 .

TABLE 3. Distribulion of the clinical types of leprosy in the natural regions of East Brazil:*

\begin{tabular}{|c|c|c|c|c|c|c|c|c|c|}
\hline \multirow{4}{*}{$\begin{array}{l}\text { Natural } \\
\text { regions }\end{array}$} & \multicolumn{8}{|c|}{ Clinical Types } & \multirow{4}{*}{ Total } \\
\hline & \multirow{2}{*}{\multicolumn{2}{|c|}{$\begin{array}{l}\text { Lepro- } \\
\text { matous }\end{array}$}} & \multicolumn{6}{|c|}{ Neural } & \\
\hline & & & \multicolumn{2}{|c|}{ Anaesthetic } & \multicolumn{2}{|c|}{$\begin{array}{l}\text { Nacular } \\
\text { simple }\end{array}$} & \multicolumn{2}{|c|}{$\begin{array}{l}\text { Macular } \\
\text { Tuberculoid }\end{array}$} & \\
\hline & No. & $\begin{array}{l}\text { l'er } \\
\text { cent }\end{array}$ & No. & $\begin{array}{l}\text { Per } \\
\text { cent }\end{array}$ & No. & $\begin{array}{l}\text { P'er } \\
\text { cent }\end{array}$ & No. & $\begin{array}{l}\text { P'er } \\
\text { cent }\end{array}$ & \\
\hline Littoral & 1,308 & 55.6 & 214 & 9.1 & 518 & 22.0 & 314 & 13.3 & 2,354 \\
\hline Coastal & 2,816 & 56.6 & 601 & 12.1 & 1,223 & 24.6 & 331 & 6.7 & 4,971 \\
\hline \multirow{2}{*}{$\begin{array}{l}\text { Highland } \\
\text { De- } \\
\text { pression }\end{array}$} & 5,833 & 64.7 & 1,316 & 14.6 & 1,588 & 17.6 & 283 & 3.1 & 9,020 \\
\hline & 232 & 62.0 & 54 & 14.5 & 61 & 16.3 & 27 & 7.2 & 374 \\
\hline TOTAI. & 10,189 & $\ldots$ & 2,185 & $\ldots$ & $3,39()$ & $\ldots$ & $9 \overline{5}$ & $\ldots$ & 16,719 \\
\hline
\end{tabular}

*232 records are excluded because of insufficient clinical data.

The Hignland zone has both the highest proportion of lepromatous cases and the lowest proportion of tuberculoid cases. 
IV. South Brazil: Included in this region are the administrative units of São Paulo, Paraná, Santa Catarina, and Rio Grande do Sul. As in the other regions, the area is divided into distinct zones. The littoral between the Atlantic Ocean and the Serra do Mar varies in width, and has the highest altitude in the state of Santa Catarina. In the so-called " cow-boy" territory, the land is low, sandy and has large lakes. Farther in the interior is a hilly region with temperate climate and with no rigorous weather.

Next comes the Intermediate Highland or Permiano, with temperate climate, pleasant summer, mild winters, and uniform rainfall throughout the year. Plantations predominate. In São Paulo is the best coffee region. In Parana there are great pine forests. The other Highland region, the Triassico, covers the greatest area but is the most sparsely populated. In the last area, the Meridion Plains, the climate is temperate, with an evenly distributed rainfall. Vegetation is abundant and the area is good for stock raising.

The prevalence of leprosy in the four administrative units shows little difference. The rates are as follows:

\begin{tabular}{|c|c|c|}
\hline São Paulo & I. 7 per & IOOO \\
\hline Paraná & I.0 , & " \\
\hline Santa Catarina & $0.5 \quad$, & "' \\
\hline Rio Grande do Sul & 0.3 & ", \\
\hline
\end{tabular}

There have been 12,900 cases of leprosy in this region. This does not necessarily mean a lower prevalence rate but probably represents a poorer reporting of cases. The distribution according to the different zones is as follows:

Littoral

Highland Permiano

Mountainous

Highland Triassico

Meridional Plains
792 cases

2778 . ,

3532 "

5326 ,

472 ,

The Highland region as can be seen has the most leprosy. Classification of these cases according to clinical type is given in Table 4.

Although there are more cases in the Triassico Highland than in the other zones, the greatest proportion of the cases in the Permiano Highland are of the more serious type.

V. West Central Region. This includes the states of Goiaz 
and Matto Grosso and is the most central region. The six natural regions in this area have been combined into the following three zones by Professor Fabio Maredo Soares Aguimaraes:

(a) Matto Grosso Highland

(b) Slopes on the right side of Paraná

(c) Central Highlands

The Matto Grosso region is generally low, rising slowly in the north.

TABLE 4. Distribution of the clinical types of leprosy in the natural regions of South Brazil*

\begin{tabular}{|c|c|c|c|c|c|c|c|c|c|}
\hline \multirow{4}{*}{$\begin{array}{l}\text { Natural } \\
\text { regions }\end{array}$} & \multicolumn{8}{|c|}{ Clinical Types } & \multirow{4}{*}{ Total } \\
\hline & \multirow{2}{*}{\multicolumn{2}{|c|}{$\begin{array}{l}\text { Lepro- } \\
\text { matous }\end{array}$}} & \multicolumn{6}{|c|}{ Neural } & \\
\hline & & & \multicolumn{2}{|c|}{ Anaesthetic } & \multicolumn{2}{|c|}{$\begin{array}{l}\text { Macular } \\
\text { simple }\end{array}$} & \multicolumn{2}{|c|}{$\begin{array}{c}\text { Macular } \\
\text { Tuberculoid }\end{array}$} & \\
\hline & No. & $\begin{array}{l}\text { Per } \\
\text { cent }\end{array}$ & No. & $\begin{array}{l}\text { Per } \\
\text { cent }\end{array}$ & No. & $\begin{array}{l}\text { Per } \\
\text { cent }\end{array}$ & No. & $\begin{array}{l}\text { Per } \\
\text { cent }\end{array}$ & \\
\hline \multirow{5}{*}{$\begin{array}{l}\text { Littoral } \\
\text { Mount- } \\
\text { ainous } \\
\text { High- } \\
\text { land P. } \\
\text { High- } \\
\text { land T. } \\
\text { Meridi- } \\
\text { onal }\end{array}$} & $\begin{array}{r}444 \\
2045\end{array}$ & 56.8 & 68 & 8.7 & 172 & 22.0 & 98 & 12.5 & $\begin{array}{r}782 \\
2505\end{array}$ \\
\hline & 2,045 & 58.0 & 120 & 3.4 & 711 & 20.2 & 649 & 18.4 & 3,525 \\
\hline & 1,825 & 66.1 & 206 & 7.5 & 409 & 14.8 & 321 & 11.6 & 2,761 \\
\hline & 3,137 & 60.0 & 331 & 6.3 & 1,171 & 22.4 & 587 & 11.3 & 5,226 \\
\hline & 192 & 49.4 & 23 & 5.9 & 53 & 13.6 & 127 & 31.1 & 389 \\
\hline TOTAL & 7,643 & $\ldots$ & 748 & $\ldots$ & 2,516 & $\ldots$ & 1,776 & $\ldots$ & 12,683 \\
\hline
\end{tabular}

*217 records are excluded because of insufficient clinical data.

In the dry months this region is a magnificent plain, but in rainy months it is a veritable waste because of the overflow of the rivers. The second region is the southwest of Matto Grosso, south of Goiaz and the Mineiro Triangle. The climate is truly tropical with two distinct seasons, the dry and the rainy. The southwestern part of this region with its splendid plains is excellent for cattle raising which is the basic industry of the area.

The Central Highlands occupies the greater part of this region. It also has a distinctly tropical climate, hot and with rainy and dry seasons. Leprosy in this region is fairly prevalent. The rates for the two administrative units are as follows:

$\begin{array}{ll}\text { Goiaz } & 2.0 \text { per Iooo persons } \\ \text { Matto Grosso } & \text { I.O ,, , , , }\end{array}$


There were records of 3,832 cases in this area distributed in the six regions as follows:

$\begin{array}{lr}\text { Highland } & 308 \text { cases } \\ \text { Half North } & 78, \\ \text { San Francisco coastal } & 215, \\ \text { Central Highlands } & 20, \\ \text { Meridional Coast } & \text { I0I6 , , } \\ \text { Near-plain of the High Paranaiba } & 2001, \\ \text { Coastal of the lower Paraguay } & \text { I94 , , }\end{array}$

This shows a greater frequency of leprosy in the near-plain of the High Paranaiba and the Meridional Coast. The distribution of the cases according to clinical type is given in table 5 .

TABle 5. Distribution of the clinical types of leprosy in the regions of West-Central Brazil*

\begin{tabular}{|c|c|c|c|c|c|c|c|c|c|}
\hline \multirow{4}{*}{$\begin{array}{l}\text { Natural } \\
\text { regions }\end{array}$} & \multicolumn{8}{|c|}{ Clinical Types } & \multirow{4}{*}{ Total } \\
\hline & \multirow{2}{*}{\multicolumn{2}{|c|}{$\begin{array}{l}\text { Lepro- } \\
\text { matous }\end{array}$}} & \multicolumn{6}{|c|}{ Neural } & \\
\hline & & & \multicolumn{2}{|c|}{ Anaesthetic } & \multicolumn{2}{|c|}{$\begin{array}{l}\text { Macular } \\
\text { simple }\end{array}$} & \multicolumn{2}{|c|}{$\begin{array}{c}\text { Maculat } \\
\text { Tuberculoid }\end{array}$} & \\
\hline & No. & $\begin{array}{r}\text { Per } \\
\text { cent }\end{array}$ & No. & $\begin{array}{l}\text { Por } \\
\text { cent }\end{array}$ & No. & $\begin{array}{l}\text { Per } \\
\text { cent }\end{array}$ & No. & $\begin{array}{r}\text { Per } \\
\text { cent }\end{array}$ & \\
\hline High- & 194 & 64.0 & 28 & 9.2 & 55 & 18.2 & 26 & 8.6 & 303 \\
\hline $\begin{array}{l}\text { Half- } \\
\text { North }\end{array}$ & 30 & 39.5 & 23 & 30.3 & 20 & 26.3 & 3 & 3.9 & 76 \\
\hline $\begin{array}{l}\text { San Fran } \\
\text { Plain }\end{array}$ & 116 & 56.6 & 34 & 16.6 & 47 & 22.9 & 8 & 3.9 & 205 \\
\hline $\begin{array}{c}\text { Central } \\
\text { Plain }\end{array}$ & 16 & 84.2 & $\ldots$ & $\cdots$ & 3 & 15.8 & $\cdots$ & $\cdots$ & 19 \\
\hline $\begin{array}{l}\text { Near- } \\
\text { Plain of } \\
\text { H. Para- } \\
\quad \text { naiba }\end{array}$ & 1,225 & 64.5 & 282 & 14.9 & 317 & 16.7 & 74 & 3.9 & 1,898 \\
\hline $\begin{array}{l}\text { Coast of } \\
\text { lower }\end{array}$ & 122 & 63.2 & 22 & 11.4 & 36 & 18.7 & 13 & 6.7 & 193 \\
\hline $\begin{array}{l}\text { Paraguay } \\
\text { Meridi- } \\
\text { onal } \\
\text { Coast }\end{array}$ & 743 & 73.9 & 107 & 10.7 & 128 & 12.7 & 27 & 2.7 & 1,005 \\
\hline TOTAL & 2,446 & $\cdots$ & 496 & $\cdots$ & 606 & $\cdots$ & 151 & $\cdots$ & 3,699 \\
\hline
\end{tabular}

*I33 cases are excluded because of insufficient clinical data.

In the regions with the largest number of cases, the proportion of lepromatous cases is also high. 


\section{COMMENTS}

The prevalence of leprosy, as shown, is high in the north region where the climate is invariably hot and humid. The hygrometric degree of the atmosphere is excessive, reaching almost the point of saturation, and in certain places registers an average humidity of 97.4 per cent throughout the year. This is most uncomfortable, causing disturbance in transpiration. The body can not free itself of the necessary heat either by transpiration or by radiation. It is well known that the two mechanisms of radiation and transpiration account for the loss of about 90 per cent of the heat produced by the body (I).

The greater prevalence in the hot and humid climates has been observed by Rogers (2) who believes that these factors are favorable for the propagation of leprosy. The same comment is made by J. J. Joseph (3) in his study on the factors influencing the prevalence of leprosy in Madras: "The hot areas which are more humid tend to show more leprosy than hot dry areas."

We agree with Mills as to the effect of a humid climate in the spread of the disease: it has a depressive effect which lowers body resistance. This follcws the changes produced by the excessive humidity on the body metabolism.

It is to be noted, also, that there are in these regions other factors, such as tropical diseases, that operate to lower the level of body resistance. On the other hand, the dietary habits have special significance. As is well known, in these regions, the diet is inadequate, being too low in calories. There is a lowering of the mineral salts which are rapidly removed from the body by the excessive perspiration to which it is constantly subjected.

In contrast to the north region the lowest prevalence of leprosy is found in the northwest region of Brazil, where the climate in a great part of the area is semi-arid with sparse rainfall that registers only 279 millimeters, as in Cabaceiras in the state of Paraiba. In the north region, the precipitation may reach almost 3000 millimeters, as occurs at S. Gabriel in the State of Amazonas. On the other hand, notwithstanding the high temperature, the relative humidity in the northwest reaches 60 per cent of what constitutes the optimum for a healthful climate. The other regions in general have a high prevalence. Relative humidity is also variable, but does not reach the extremes of the north and northwest regions.

As to clinical type, in the two regions of the north and the northwest, the lowest proportion of the lepromatous type occurs. It 
must be noted also that in one of the natural zones of the eastcentral region, the Half-North, where the climatic conditions approach those found in the state of Amazonas there is a low proportion of lepromatous cases. In these two regions also the lowest proportions of the tuberculoid types are found.

In Table 6 the proportion of cases of the different clinical types are given for the various regions of the country.

In order to study more thoroughly the interdependence of climatic factors and the prevalence of leprosy it might be well to study the appearance of cases in temperate regions in which variation in atmospheric conditions cause, at certain times, conditions very similar to those found in tropical regions with hot and humid climate.

TABLE: 6. Comparison of the prevalence of the clinical types of leprosy in the varions physiographic regions of Brazil

\begin{tabular}{|c|c|c|c|c|c|c|c|c|c|}
\hline \multirow{4}{*}{$\begin{array}{l}\text { Physio- } \\
\text { graphic } \\
\text { regions }\end{array}$} & \multicolumn{8}{|c|}{ (linical Types } & \multirow{4}{*}{ Total } \\
\hline & \multirow{2}{*}{\multicolumn{2}{|c|}{$\begin{array}{l}\text { I-epro- } \\
\text { matous }\end{array}$}} & \multicolumn{6}{|c|}{ Neural } & \\
\hline & & & \multicolumn{2}{|c|}{ Anaesthetic } & \multicolumn{2}{|c|}{$\begin{array}{l}\text { Macular } \\
\text { simple }\end{array}$} & \multicolumn{2}{|c|}{$\begin{array}{c}\text { Macular } \\
\text { Tuberculoid }\end{array}$} & \\
\hline & No. & $\begin{array}{l}\text { Per } \\
\text { cent }\end{array}$ & No. & $\begin{array}{l}\text { Per } \\
\text { cent }\end{array}$ & No. & $\begin{array}{l}\text { Per } \\
\text { cent }\end{array}$ & No. & $\begin{array}{l}\text { Per } \\
\text { cent }\end{array}$ & \\
\hline $\begin{array}{l}\text { North } \\
\text { Nor'east } \\
\text { East } \\
\text { South } \\
\text { West- } \\
\text { Cicntral }\end{array}$ & $\begin{array}{r}1,412 \\
1,602 \\
10,187 \\
7,643 \\
2,446\end{array}$ & $\begin{array}{l}51.7 \\
55.9 \\
60.9 \\
60.3 \\
66.1\end{array}$ & $\begin{array}{c}743 \\
416 \\
2,165 \\
748 \\
496\end{array}$ & $\begin{array}{r}27.2 \\
14.5 \\
13.1 \\
5.9 \\
16.4\end{array}$ & $\begin{array}{c}190 \\
753 \\
3,390 \\
2,516 \\
306\end{array}$ & $\begin{array}{l}17.9 \\
26.3 \\
20.3 \\
19.8 \\
13.4\end{array}$ & $\begin{array}{r}88 \\
96 \\
955 \\
1,776 \\
151\end{array}$ & $\begin{array}{r}3.2 \\
3.3 \\
5.7 \\
14.0 \\
4.1\end{array}$ & $\begin{array}{r}2,433 \\
2,8.57 \\
16,697 \\
12,683 \\
3,699\end{array}$ \\
\hline TOTAL & 4,290 & $\cdots$ & 4,568 & $\cdots$ & 7,455 & $\cdots$ & 3,066 & .. & 38,701 \\
\hline
\end{tabular}

It is possible that the appearance of new cases may follow a certain cycle, having periods of greater frequency of the disease, or seasonal outbreaks, such as happen in many infectious diseases. The clinical characteristics of leprosy are so peculiar as to cause great difficulties in such a study, because of the uncertainty of tine period of incubation and the reporting of first symptoms, as well as variability in the evolution of the disease. Nevertheless, by making more frequent intensive censuses such as that made in Cebu and such as those now being made by the National Leprosy Service, we shall have more exact information for better study of the basic reasons causing the spread of leprosy. 


\section{CONCLUSions}

I. The spread of leprosy is influenced by propitious climatic conditions.

2. Among climatic elements, the relative humidity of the air is the factor of greatest importance in determining favorable conditions for the spread of the disease.

3. High temperature and high relative humidity appear to favor the spread of the disease more by adversely affecting the body metabolism than by an indirect effect by favoring the transmission of the disease.

4. In the north and northeast regions the lowest proportions of the lepromatous type are found, which does not seem to correspond to the theory of greater individual resistance; inasmuch as the lowest proportion of the tuberculoid type is also found in these regions.

5. It appears, in view of the relative frequency of the various clinical types in different regions, that the excess of relative humidity favors a modification of the body defense, thus increasing the possibility of the spread of the disease. A high temperature acts as a factor which gives a less severe course to the evolution of leprosy, since it is admitted that temperate or cold climate favors the more acute development of the disease (4).

\section{REFERENCES}

(1) Best, C. H. and TAYLOR, N. B. The physiological basis of medical practice. Third Edition. The Williams and Wilkins Co., Baltimore, 1943. (First Portuguese Edition (1940 p. 1051.)

(2) Rogers, Leonard. The world incidence of leprosy in relation to meteorological conditions and its bearing on the probable mode of transmission. Tr. Roy. Soc. Trop, Med. \& Hyg. 16 (1923) 440.

(3) Joseph, J. J. The incidence of leprosy in the Madras Residence District. Leprosy in India 11 (1938) 36.

(4) Shionuma, E., Nagai, K., and Madea, T. The climate theory in leprosy Internat. J. I.eprosy 6 (1938) 315. 